ism. With glycine Table 1 shows that the plateau SA of free glycine was always higher in liver than in muscle. This perhaps fits in with the suggestion made by Henriques et al. ${ }^{1}$ that there is a barrier to the entry of glycine into muscle.

I thank Dr David Picou for the glycine analyses on the automatic amino-acid analyser and Professor J. C. Waterlow for his advice.

MRC Tropical Metabolism Research Unit,

St Mary's Hospital,

London W2.

Received February 11, 1969.

${ }^{1}$ Henriques, O. B., Henriques, S. B., and Nenberger, A., Biochem. J., 60, 409 (1955).

2 Waterlow, J. C., and Stephen, J. M. L., Clin. Sci., 33, 489 (1967),

${ }^{3}$ Waterlow, J. C., and Stephen, J. M. T., Clin. Sci., 35, 287 (1968).

4 Thin Layer Chromatography (edit. by Stahl, E.), 424 (Springer-Terlag, Berlin, 1965).

\section{Effect of the Inhibition of RNA Synthesis on in vitro Ovulation by Frog Ovaries}

OVULATion can be stimulated in isolated segments of frog ovary by the addition of hormones ${ }^{1,2}$ but is prevented by actinomycin $D^{3}$; this has led to the suggestion that ovulation is contingent on the synthesis of $\mathrm{RNA}^{3,4}$. Indeed, actinomycin $D$ is known to inhibit RNA synthesis in ovaries as well as ovulation ${ }^{4}$, while hormonal stimulation is followed by increased uridine incorporation into the cells of the peritoneal surface of the ovary ${ }^{5}$, through which ovulation occurs.

Actinomyein $D$, however, has effects other than those usually assigned to $i^{6-8}$ and ovulation following hormonal stimulation could result from the translation of preformed, stable messenger RNA, like that in the fertilized sea urchin egg ${ }^{2}$. Actinomycin $D$ might prevent ovulation by interfering with translation. We have performed experiments with the drugs 2-mercapto-1-( $\beta$-4-pyridethyl) benzimidazole (MPB), 1-diethylaminoethylamino-4-methyl10-thiaxanthone (M-D), a gift from the Burroughs Wellcome Co., Inc., and actinomycin $D$ to determine whether transcription of new RNA is the chief process responsible for hormonally stimulated ovulation in the frog. M-D inhibits RNA synthesis by binding to DNA in a manner similar to that proposed for ectinomycin $D$ (ref. 10). It has been suggested that MPB functions by either interfering with an early stage of purine or pyrimidine metabolism or by the activation of an inhibitory foedback mechanism ${ }^{11}$. MPB is structurally quite different from actinomyein $D$ and would not be expected to have the sarne side effects as actinomycin $D$, whereas M-D is structurally similar to actinomycin $D$ and provided another test with a drug that blocks RNA synthesis by binding to DNA.

Ovaries from fomalo frogs (Rana pipiens) that had been maintained at $3^{\circ}-4^{\circ} \mathrm{C}$ were cut into clusters of twenty to twenty-five eggs and placed in glass vials containing $8 \mathrm{ml}$. of frog Ringer's solution. In each experiment a single frog was used. Ovulation was induced by the addition of progesterone ( $16 \mu \mathrm{g}$ per vial dissolved in $25 \mu \mathrm{l}$. of 50 per cent ethanol) added at the same timo as the antibiotic. MPB was dissolved in $25 \mu \mathrm{l}$. of dimethyl-sulphoxide (DMSO) and M-D dissolved in $200 \mu \mathrm{l}$. of Ringer's solution containing $25 \mu \mathrm{l}$. of DMSO, whereas actinomycin $D$ was dissolved in $200 \mu \mathrm{l}$. of a $0.001 \mathrm{M}$ phosphate buffer containing $0.01 \mathrm{M} \mathrm{NaCl}$ at a final $p \mathrm{H}$ of $7 \cdot 1$. In experiments with labelled precursor, vials containing $4 \mu \mathrm{Ci} / \mathrm{ml}$. of ${ }^{3} \mathrm{H}$ uridine were stoppered with cotton plugs and kept in the dark at $23^{\circ} \pm 2^{\circ} \mathrm{C}$ for $6 \mathrm{~h}$. Vials containing ovaries without ${ }^{3} \mathrm{H}$-uridine were allowed to stand for $24 \mathrm{~h}$, then omptied into a Petri dish, and the percentage of ovulation recorded.
For RNA and DNA analysis, egg clusters were ruptured by pressing against a stainless steel screen, and the remaining tissue was washed with cold distilled water to remove traces of egg materials. For RNA, DNA and radioactivity determination ${ }^{12}$ it was necessary first to prepare such ovarian tissue without mature ova from three clusters. Plots of the log of the drug dose against per cent ovulation and per cent DPM/mg DNA relative to ovaries treated with progesterone indicated that, regardless of which drug was used, when enough was added to reduce RNA synthesis in ovarian tissue by 15-25 per cent there was a concomitant 50 per cent reduction in the number of ovulations (Table 1 ).

Table 1. THE EFFECT OF VARIOUS ANTISETABOLITES ON PROGESTERONE STIMULATED OVULATION AND ${ }^{3} \mathrm{H}$-URIDINE INCORPORATION BY YROG OVARIAN TISSUE in vitro

\begin{tabular}{|c|c|c|c|c|}
\hline Treatment & $\begin{array}{c}\text { Dose } \\
\mu \mathrm{gg} / \mathrm{ml} \text {. }\end{array}$ & $\begin{array}{l}\mathrm{DPM} \times 10^{-5} / \\
\mathrm{mg} \mathrm{DNA}^{*}\end{array}$ & $\begin{array}{c}\text { Per cent } \dagger \\
\text { DPMI }\end{array}$ & $\begin{array}{l}\text { Relative } \\
\text { ovulation' }\end{array}$ \\
\hline$M-D$ & $\begin{array}{r}1.00 \\
10.00 \\
100 \cdot 00\end{array}$ & $\begin{array}{l}7.45 \\
7.02 \\
3.72\end{array}$ & $\begin{array}{l}83 \cdot 3 \\
78 \cdot 5 \\
41 \cdot 6\end{array}$ & $\begin{array}{r}81.2 \\
16.5 \\
4.4\end{array}$ \\
\hline$M P B$ & $\begin{array}{r}0.50 \\
5.00 \\
25.00\end{array}$ & $\begin{array}{l}7 \cdot 56 \\
4 \cdot 30 \\
2 \cdot 43\end{array}$ & $\begin{array}{l}84 \cdot 6 \\
48 \cdot 1 \\
27 \cdot 2\end{array}$ & $\begin{array}{c}59 \cdot 6 \\
0 \\
0\end{array}$ \\
\hline Actinomyein $D$ & $\begin{array}{l}0 \cdot 01 \\
0 \cdot 10 \\
1 \cdot 00\end{array}$ & $\begin{array}{l}8 \cdot 43 \\
7 \cdot 76 \\
4 \cdot 41\end{array}$ & $\begin{array}{l}99 \cdot 6 \\
91 \cdot 7 \\
52 \cdot 1\end{array}$ & $\begin{array}{c}93 \cdot 3 \\
65 \cdot 6 \\
0\end{array}$ \\
\hline
\end{tabular}

* 'These data are from a typical experiment which has been repeated a minimum of three times.

+ Represents the per cent of the progesterone-only treated value and is the average of the ovarian segments from three separate vials.

Hechter et al. ${ }^{13}$ have suggested that steroid hormone effects in vitro may be mediated through the action of $3^{\prime}, 5^{\prime}$ eyclic AMP by a mechanism not related to genetic transcription. The addition of as much as $100 \mu \mathrm{g} / \mathrm{ml}$. of either $3^{\prime}, 5^{\prime}$ cyclic AMP or dibutyryl cyclic AMP in the presence of DMSO, however, did not influence ovulation in either progesterone-treated or control frog ovaries in vitro (our unpublished result). These results, in conjunction with the experiments with actinomycin $D^{3,4}$, support the idea that hormonally stimulated ovulation by the frog ovary is contingent on synthesis of new RNA and its subsequent translation.

The data reported here also support the hypothesis that new RNA is required because it is unlikely that compounds which differ markedly in structure and appal'ent mode of action would have the same side effocts as actinomycin $D$.

We thank Mrs Nancy Brown for technical assistance and Dr John W. Anderson for his advice.

This investigation was supported in part by a US Public Health Service grant from the National Cancer Institute and a research career development award to one of us (M. B. Y.).

\section{Mitton B. Yatvin} Henry C. Pitot

Radiobiology Research Laboratories,

Departments of Radiology and Pathology,

University of Wisconsin Medical School,

Madison, Wisconsin 53706.

Received February 18; revised April 24, 1969.

1 Wright, P. A., J. Exp. Zool., 100, 565 (1945).

${ }^{2}$ Edgren, R. A., and Carter, D. L., Gen. Comp. Endocrinol., 3, 526 (1963), (1963).

${ }^{3}$ Dettlaff, T. A., J. Embryol. Exp. Morphol., 16, 183 (1966).

${ }^{4}$ Yatvin, M. B., and Anderson, J. W., Fed. Proc., 26, 535 (1967).

${ }^{3}$ Anderson, J. W., and Yatvin, M. B., J. Cell. Biol, 35, 4A (1967),

- Revel, M., Miatt, H. H., and Rovel, J-P, Science, 148, 1311 (1964).

7 Honig, G. R., and Rabinovitz, M., Science, 149, 1504 (1965).

${ }^{8}$ Laszlo, J., Miller, D. S., McCarthy, K. S., and Hochstein, P., Science, 151, 1007 (1966).

${ }^{9}$ Monroy, A.. Magrio, R., and Rinaldi, A. M., Pros. US Nat. Acad.Sci., 54, 107 (1965).

${ }^{10}$ Weinstein, I., Carchman, R., Marner, E., and Hirschbarg, E., Biochim. Biophys. Acta,142, 440 (1967).

${ }^{11}$ Bucknall, R. A., and Carter, S. B., Nature, 213, 1099 (1967).

${ }^{12}$ Wannemacher, jun., R. W., Banks, jun., W. I., and Wunner, W. H., Anal. Biochem.,11, 320 (1965).
annemacher, jun.,

${ }^{13}$ Hechter, O., Yoshinaga, K., Halkerston, I. D. K., and Birchall, K., Arch. Biochem. Biophys.,122, 449 (1967). 